\title{
DEVELOPMENT OF WINTER WHEAT BLOTCHES DEPENDING ON FUNGICIDE TREATMENT SCHEMES AND NITROGEN RATES
}

\author{
*Agrita Švarta, Gunita Bimšteine, Zinta Gaile, Terēze Stanka, Linda Daugaviņa, Ieva Plūduma-Pauniṇa \\ Latvia University of Life Sciences and Technologies, Latvia \\ *Corresponding author's email: agrita.svarta@1lu.lv
}

\begin{abstract}
One of the factors affecting winter wheat grain yields are leaf blotches. The two-factorial trial was conducted in the Research and Study farm 'Pēterlauki' in 2017/2018 and 2018/2019 (Latvia). Four nitrogen rates and five fungicide treatment schemes were used. The aim was to clarify the impact of leaf blotches on the winter wheat yield. In winter wheat plots, the tan spot (caused by Pyrenophora tritici-repentis) dominated but also Septoria leaf blotch (caused by Zymoseptoria tritici) was found. The severity of leaf blotches in winter wheat was low in both years due to dry and warm weather. The development of leaf blotches was influenced by fungicide application schemes, but not by nitrogen fertilizer rate. The total disease impact during the vegetation period was estimated by calculation the area under the disease progress curve (AUDPC). AUDPC for both diseases were significantly higher in the variant without fungicides (F0) and in the variant, where half of dose of fungicides at the growth stage (GS) 55-59 (F1) was used. The using of full dose of fungicide at the GS 55-59 (F2) as well as using of fungicides two (F3) or three (F4) times in growing season significantly decreased the values of AUDPC for both diseases, but differences among AUDPC values in mentioned three variants were not significant. Results showed that the nitrogen fertilization significantly increased the average per both years grain yield until the nitrogen rate N180. Fungicide treatment schemes had no significant effect on the average grain yield.
\end{abstract}

Key words: Pyrenophora tritici-repentis, Zymoseptoria tritici, control, yield, values of AUDPC.

\section{Introduction}

The grain yield is influenced by the interaction of a number of factors such as cultivar, meteorological conditions and nitrogen fertilizers. Researches confirm that nitrogen fertilization significantly increased winter wheat grain yield, but increase of yield depends on the used rate of nitrogen (Litke, Gaile, \& Ruža, 2017; Linina \& Ruza, 2018).

An important factor affecting winter wheat grain yields is leaf blotches. In Latvia, the most widespread wheat leaf diseases are tan spot (caused by Pyrenophora tritici-repentis) and Septoria leaf blotch (caused by Zymoseptoria tritici) (Bankina et al., 2014; Bankina et al., 2018a).

The losses of winter wheat yield can range from 10-74\% (Wegulo, Breathnach, \& Baenziger, 2009; Wiik, 2009; Jevtić et al., 2017; Bhatta et al., 2018) and depend on development stage at which the infection occurs (Serrago et al., 2011). The occurrence of diseases depends considerably on meteorological conditions (Wyczling, Lenc, \& Sadowski, 2010; Bankina et al., 2014; Jevtić et al., 2017; Bankina et al., 2018a), agrotechnical practices (Bankina et al., 2018a) and fertilisation (Castro et al., 2018).

The leaf blotches decrease green leaf area (Wyczling, Lenc, \& Sadowski, 2010; Bhatta et al., 2018), but the photosynthesis during grain filling period ensure dry matter accumulation in the grain, including nitrogen. The fungicide treatment strategies are aimed to protect leaves, particularly the flag leaf, and delay the senescence (Castro et al., 2018). The yield benefits from fungicide application and not only depends on the amount of rainfall at all important growth stages for yield formation (Bhatta et al., 2018), but also on the frequency of the rainfall. Frequent rainfall provided conditions for continued pressure of tan spot and Septoria tritici blotches (Wyczling, Lenc, \& Sadowski, 2010; Ronis \& Semaškiene, 2011; Byamukama et al., 2019).

The aim of this research was to clarify the impact of leaf blotches on the winter wheat yield under four nitrogen rates and five fungicide treatment schemes.

\section{Materials and Methods}

Two-factorial field trials were conducted at the Research and Study farm 'Pēterlauki' of Latvia University of Life Sciences and Technologies $\left(56^{\circ}\right.$ $54.367^{\circ} \mathrm{N}$ and $23^{\circ} 72.220^{\circ}$ ) in the growing seasons of 2017/2018 and 2018/2019. Researched factors were: (A) five different fungicide treatment schemes (Table 1) and (B) four nitrogen fertilizer rates were used $(\mathrm{N} 120(80+40), \mathrm{N} 150(80+70), \mathrm{N} 180(80+70+30)$ and $\mathrm{N} 210(80+80+50)$. In total, twenty variants were arranged in four replications.

The winter wheat cultivar 'Skagen' was used in the trial. This cultivar is characterized by good productivity and winterhardiness. Sowing rate depended on sowing time and trial meteorological conditions: 450 germinable seeds $\mathrm{m}^{-2}$ in 2017/2018 and 500 germinable seeds $\mathrm{m}^{-2}$ in 2018/2019. In 2018, wheat sowing was delayed to the end of September due to adverse weather conditions, and in this case, sowing rate was increased a little.

The soil at the site was loamy, stagnogley. The soil is characterized by the following indicators depending on the year: $\mathrm{pH} \mathrm{KCL}=6.4-7.0$, organic matter content 29-42 $\mathrm{g} \mathrm{kg}^{-1}, \mathrm{P}_{2} \mathrm{O}_{5}$ content $118-138 \mathrm{mg} \mathrm{kg}^{-1}$ and $\mathrm{K}_{2} \mathrm{O}$ content $208-262 \mathrm{mg} \mathrm{kg}^{-1}$ of the soil. 


\section{The fungicide treatment schemes}

\begin{tabular}{|c|c|c|c|}
\hline \multirow{2}{*}{ Variant } & \multicolumn{2}{|c|}{ Used fungicides } & \multirow{2}{*}{$\begin{array}{l}\text { Treatment timing - growth stage } \\
\text { (GS) according } \mathrm{BBCH}^{*}\end{array}$} \\
\hline & active ingredients of fungicides & dose, $\mathrm{L} \mathrm{ha}^{-1}$ & \\
\hline F0 & Without fungicides & - & - \\
\hline F1 (one treatment 0 & $\begin{array}{l}\text { Protioconazole } 130 \mathrm{~g} \mathrm{~L}^{-1} \text {; } \\
\text { bixafen } 65 \mathrm{~g} \mathrm{~L}^{-1} \text {; } \\
\text { fluopyram } 65 \mathrm{~g} \mathrm{~L}^{-1}\end{array}$ & 0.750 & $55-59$ \\
\hline F2 (one treatment) & $\begin{array}{l}\text { Protioconazole } 130 \mathrm{~g} \mathrm{~L}^{-1} \text {; } \\
\text { bixafen } 65 \mathrm{~g} \mathrm{~L}^{-1} \text {; } \\
\text { fluopyram } 65 \mathrm{~g} \mathrm{~L}^{-1}\end{array}$ & 1.500 & $55-59$ \\
\hline \multirow[b]{2}{*}{ F3 (two treatments) } & $\begin{array}{l}\text { Protioconazole } 160 \mathrm{~g} \mathrm{~L}^{-1} \\
\text { spiroxamin } 300 \mathrm{~g} \mathrm{~L}^{-1}\end{array}$ & 0.625 & $32-33$ \\
\hline & $\begin{array}{l}\text { Protioconazole } 130 \mathrm{~g} \mathrm{~L}^{-1} \text {; } \\
\text { bixafen } 65 \mathrm{~g} \mathrm{~L}^{-1} \text {; } \\
\text { fluopyram } 65 \mathrm{~g} \mathrm{~L}^{-1}\end{array}$ & 0.750 & $55-59$ \\
\hline \multirow{3}{*}{ F4 (three treatments) } & $\begin{array}{l}\text { Protioconazole } 160 \mathrm{~g} \mathrm{~L}^{-1} \\
\text { spiroxamin } 300 \mathrm{~g} \mathrm{~L}^{-1}\end{array}$ & 0.625 & $32-33$ \\
\hline & $\begin{array}{l}\text { Protioconazole } 130 \mathrm{~g} \mathrm{~L}^{-1} \text {; } \\
\text { bixafen } 65 \mathrm{~g} \mathrm{~L}^{-1} \text {; } \\
\text { fluopyram } 65 \mathrm{~g} \mathrm{~L}^{-1}\end{array}$ & 0.750 & $55-59$ \\
\hline & Metconazole $90 \mathrm{~g} \mathrm{~L}^{-1}$ & 1.000 & $63-65$ \\
\hline
\end{tabular}

* $\mathrm{BBCH}$ - the phenological growth stages of cereals according to the 'Biologisce Bundesanstalt, Bundessortenamt und Chemische Industrie'(BBCSH) scale.

Before sowing, fertilizer was applied $\mathrm{N}-25 \mathrm{~kg} \mathrm{ha}^{-1}$, $\mathrm{P}_{2} \mathrm{O}_{5}-65 \mathrm{~kg} \mathrm{ha}^{-1}, \mathrm{~K}_{2} \mathrm{O}-65 \mathrm{~kg} \mathrm{ha}^{-1}$. Weeds were controlled using herbicides in both years: in 2018, granstar premia $50 \mathrm{SX}$ (methyl-tribenuron $500 \mathrm{~g} \mathrm{~kg}^{-1}$ ) $22 \mathrm{~g} \mathrm{ha}^{-1}+$ Primus (florasulam $50 \mathrm{~g} \mathrm{~L}^{-1}$ ) $0.1 \mathrm{~L} \mathrm{ha}^{-1}$ at 07.05.2018., in 2019, biathlon 4D(tritosulfuron $714 \mathrm{~g} \mathrm{~kg}^{-1}$; florasulam $54 \mathrm{~g} \mathrm{~kg}^{-1}$ ) + adjuvant Dash $0.5 \mathrm{~L} \mathrm{ha}^{-1}$ in were used. In spring, after the vegetation renewing, nitrogen fertilizer $\left(\mathrm{NH}_{4} \mathrm{NO}_{3}\right.$; $\left.\mathrm{N} 34.4 \%\right)$ was applied for all investigated variants. The second topdressing was done at GS 29-31 using ammonium sulphate $\left(\left(\mathrm{NH}_{4}\right)_{2} \mathrm{SO}_{4} ; \mathrm{N} 21 \%, \mathrm{~S} 24 \%\right)$ at the rate $100 \mathrm{~kg} \mathrm{ha}^{-1}$. The remaining amount of needed nitrogen was added using ammonium nitrate $\left(\mathrm{NH}_{4} \mathrm{NO}_{3}\right.$; $\mathrm{N} \mathrm{34.4 \% ).} \mathrm{The} \mathrm{third} \mathrm{top-dressing} \mathrm{was} \mathrm{done} \mathrm{at} \mathrm{GS} \mathrm{47-}$ 51 with ammonium nitrate. The rate of nitrogen was divided into two applications for variants N120 and N150, and into three applications - for variants N180 and $\mathrm{N} 210$.

After harvesting, grain was weighed, grain purity and moisture content detected and yield data were recalculated to standard moisture (14\%) and 100\% purity.

The incidence and severity of the disease were evaluated for the whole plant at the growth stage (GS) of the beginning of stem elongation (GS31), for the 3 upper leaves at the stages 'Flag leaf just visible' till 'flag leaf stage: flag leaf fully unrolled, ligule just visible' (GS 37-39) and the full flowering (GS
63-65), for the 2 upper leaves - at the stage of early milk (GS 73) and at the stage of late milk (GS 75-79). Growth stages were noted according to $\mathrm{BBCH}$ scale. In the first assessment, 50 plants were evaluated. In further assessments, 50 leaves were evaluated from every plot, proportionally taking the flag leaves, the first leaves and the second leaves. The total disease impact during the vegetation period was estimated by calculating the area under the disease progress curve (AUDPC).

For data statistical processing the analysis of variance was used. R-Studio for data processing was used. Bonferroni test was used for the comparison of means, the differences were considered statistically significant when $p<0.05$. Significantly different means were labelled with different letters in superscript $\left({ }^{a, b}\right)$. The relationship between the winter wheat yield and the development of leaf blotch was analyzed by correlation analyses.

The meteorological data were summarized according to growth stages when the evaluation of diseases was done (Table 2). The weather conditions slightly differed during the years of investigation. The air temperatures were higher than long-term observations in the both trial years. There was a significant difference between vegetation starting dates (respectively - on 3 April 2018 and on 15 March 2019). The time from the starting of vegetation till the stage of stem elongation was relatively short (34 days) 


\section{Meteorological conditions during the period of investigation}

\begin{tabular}{|c|c|c|c|c|}
\hline \multirow{3}{*}{ Year } & Growth stages & $\begin{array}{c}\text { Average temperature, } \\
{ }^{\circ} \mathrm{C}\end{array}$ & $\begin{array}{c}\text { Amount of precipitation, } \\
\mathrm{mm}\end{array}$ & $\begin{array}{c}\text { Number of rainy days } \\
(>2 \mathrm{~mm})\end{array}$ \\
\hline \multirow{4}{*}{2018} & $31-39$ & 16.2 & 4 & 1 \\
\cline { 2 - 5 } & $39-65$ & 17.6 & 2 & 0 \\
\cline { 2 - 5 } & $65-73$ & 17.9 & 0 & 0 \\
\cline { 2 - 5 } & $73-79$ & 15.8 & 14 & 1 \\
\hline \multirow{3}{*}{2019} & $31-39$ & 13.3 & 14 & 0 \\
\cline { 2 - 5 } & $39-65$ & 16.3 & 5.8 & 0 \\
\cline { 2 - 5 } & $65-73$ & 20.5 & 1.6 & 1 \\
\cline { 2 - 5 } & $73-79$ & 18.8 & 6.2 & 3 \\
\hline
\end{tabular}

and with an increased amount of precipitation in April 2018, but in 2019, this period was 52 days long. There was no precipitation in April 2019. Lack of moisture at all important growth stages for yield formation was observed. Overall, the meteorological situation was unfavourable for the plant growth and development in both trial years.

\section{Results and Discussion}

The development of leaf blotches

In winter, wheat plots, the tan spot (caused by Pyrenophora tritici-repentis) dominated, but also Septoria leaf blotch (caused by Zymoseptoria tritici) was found. Differences in the development of leaf blotches in each trial year separately were described in previous publications (Bankina, Stanka, \& Grickeviča, 2018b; Stanka, Bankina, \& Daugavinga, 2019).

The incidence and severity of leaf blotches in winter wheat was low in both years. Dry and warm weather delayed the development of leaf blotches. It is known, that precipitation is necessary for the development of leaf blotches. Especially the causal agent of Septoria leaf blotch requires a moist leaf surface for successful infection. The pathogen spread throughout the crop canopy via rain splash originating (Castro et al., 2018).

The tan spot progression during the vegetation period is shown in Figure 1. The first symptoms of tan spot were observed already at GS 31-32, but the development of disease was slow and similar till GS 71-73 in all fungicide treatment schemes. Rapid development of tan spot began at the time of ripening of grains. The highest severity of tan spot (10.4\%) was obtained in control variant where winter wheat was grown without the application of fungicides. With the application of fungicides, the severity of tan spot decreased until 3.6-6.1\%.

Septoria leaf blotch started later, the first symptoms were observed only at the flag leaf stage (GS 37-39). Overall, the progression of Septoria leaf blotch was slower than that of tan spot (Figure 2). The highest severity of Septoria leaf blotch $(3.7 \%)$ was obtained in control variant where winter wheat was grown without the application of fungicides. The application

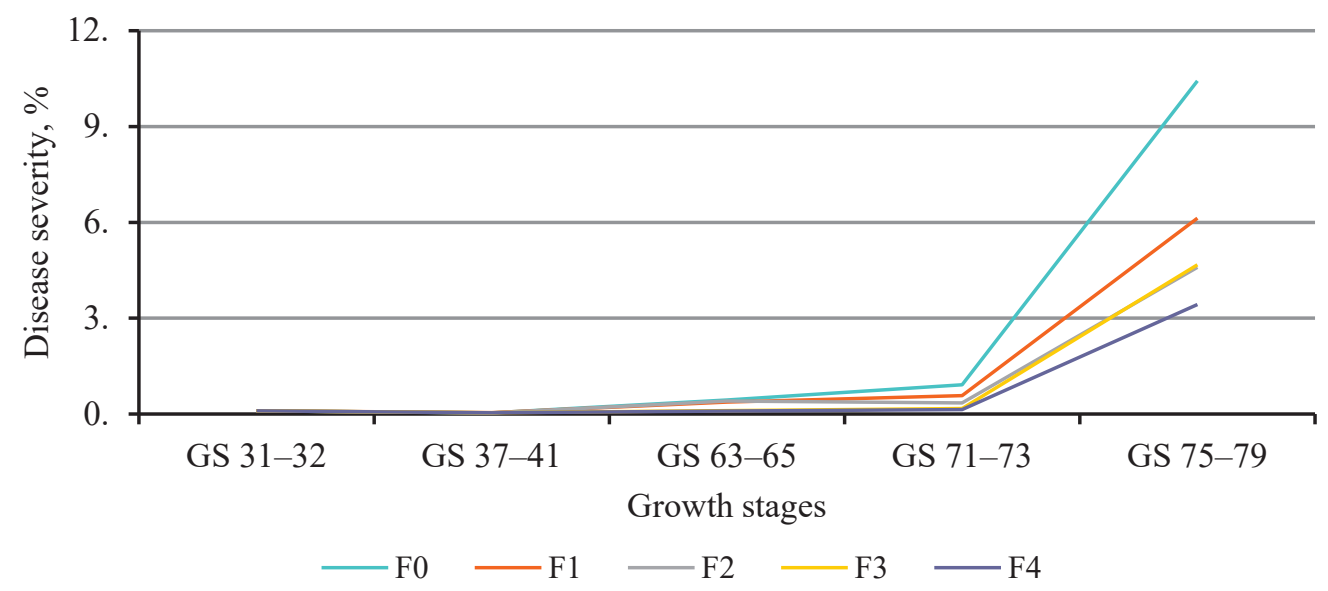

Figure 1. Development of tan spot depending of fungicide treatment schemes (average data per 2017/2018-2018/2019). 


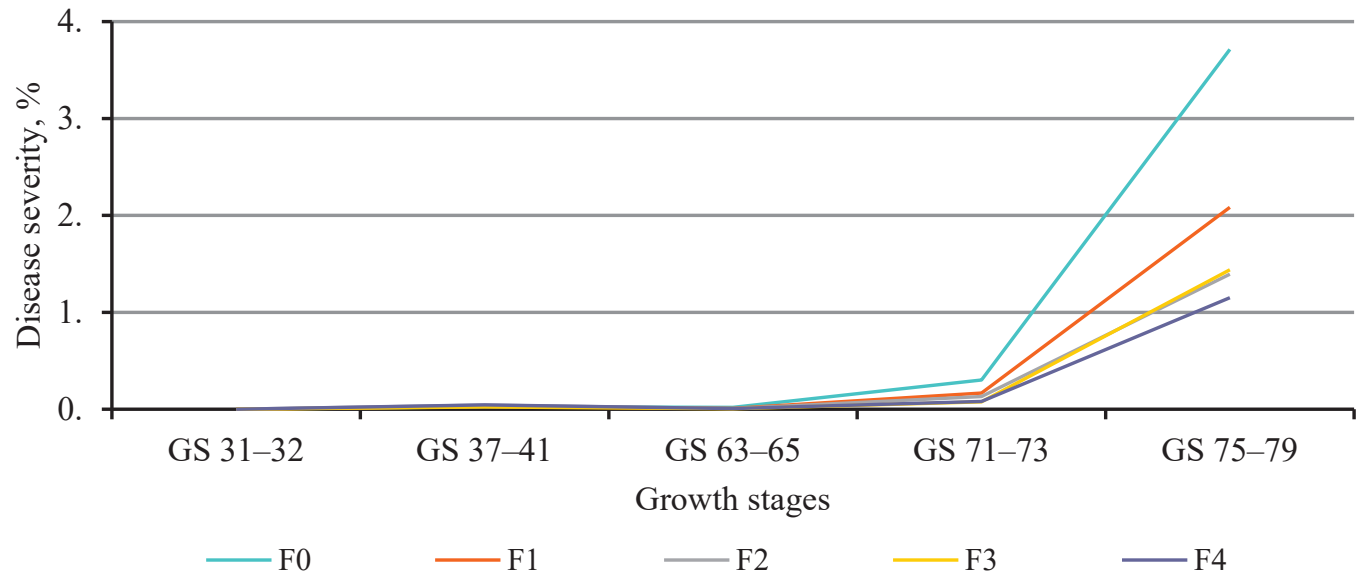

Figure 2. Development of Septoria leaf blotch depending on fungicide treatment schemes (average data per 2017/2018-2018/2019).

of fungicides decreased the severity of Septoria leaf blotch until $1.2-2.1 \%$.

The total impact of diseases during the vegetation period depending on fungicide treatment scheme is shown by AUDPC (Figure 3). The development of leaf blotches was influenced by fungicide application schemes $(\mathrm{p}<0.001$ for both diseases), but not by nitrogen fertilizer rate $(p=0.47$ for tan spot, $p=0.97$ for Septoria leaf botch). Some studies have reported that $\mathrm{N}$ fertilization may also affect distribution of foliar diseases. For example, in Argentina researchers found that only in the wettest years with more disease pressure, severity of Septoria leaf blotch and tan spot significantly decreased when the $\mathrm{N}$ rate increased, but in the dry years no differences were detected (tested variants - N0, N70 and N140 $\mathrm{kg} \mathrm{ha}^{-1}$ ) (Castro et al., 2018). In another research Fleitas et al. (2018) found that, in untreated variants, the values of AUDPC for $\tan$ spot were lower with higher $\mathrm{N}$ rates.
Differences of AUDPC values for tan spot between variants of fungicide treatment schemes ranged between 24.4 and 77.4 units. Values of AUDPC were the highest in the control variant without fungicides (F0). The differences among the variants of different schemes were also significant. In variant F1, where half of dose of fungicides at the GS 55-59 was applied, the decrease of AUDPC units was not significant ( $p$ $=0.06$ ) in comparison with control variant (F0). The significant decrease of the development of tan spot was obtained in variant with full dose of fungicide application at the GS 55-59 (F2) and in variants where winter wheat was treated with fungicides two (F3) or three (F4) times in the growing season. The differences of AUDPC values among these fungicide treatment schemes (F2, F3 and F4) were not significant.

The differences of AUDPC values for Septoria leaf blotch (Figure3) between variants of fungicide treatment schemes ranged between 8.4 and 26.0 units.

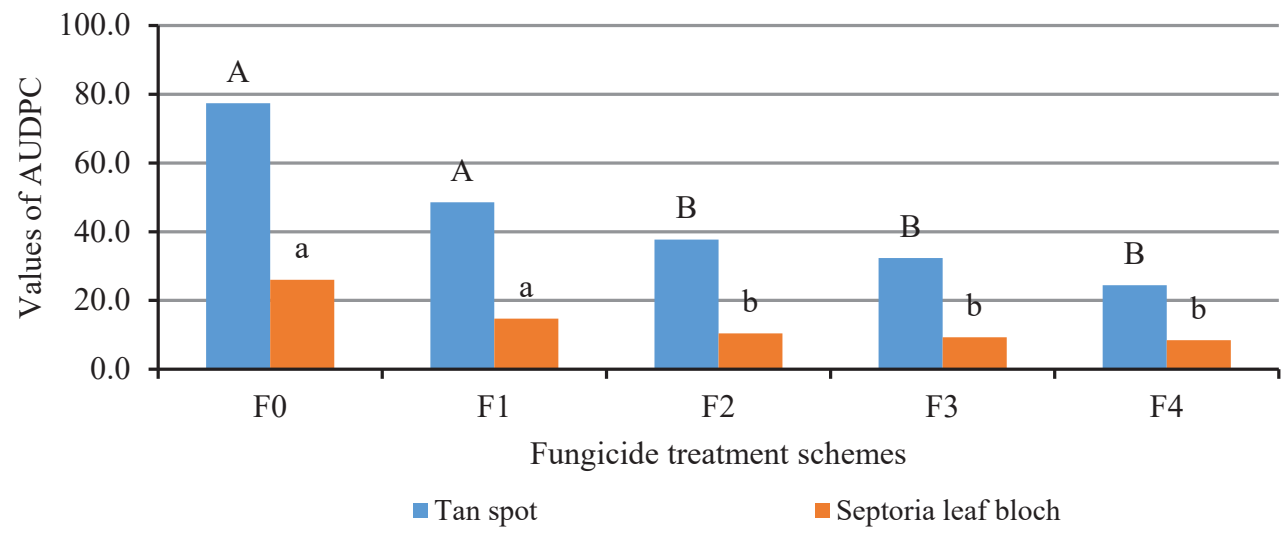

Figure 3. Values of areas under the disease progress curve (AUDPC) of leaf blotches depending on fungicide treatment schemes (average data 2017/2018-2018/2019).

Different letters denote significant differences:

A, B - for average values of AUDPC for tan spot;

a, b - for average values of AUDPC for Septoria leaf blotch. 


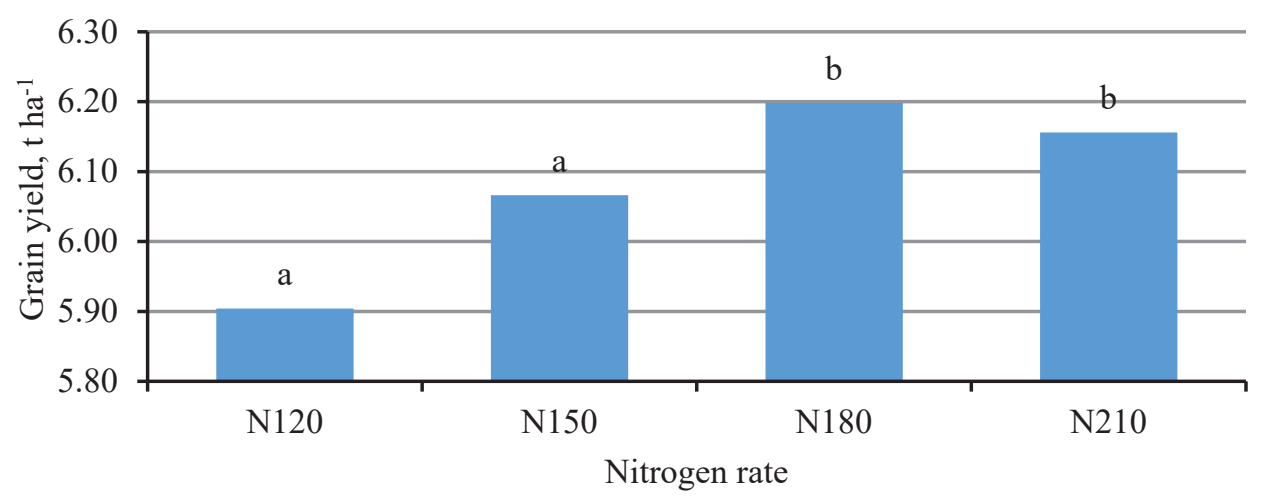

Figure 4. Winter wheat grain yield depending on the nitrogen rate (average data, 2017/2018-2018/2019). Different letters denote significant differences: ${ }^{\mathrm{a}, \mathrm{b}}$ - for average yields of two trial years.

The influence of fungicide treatment schemes on the development of Septoria leaf blotch was similar to that of tan spot.

The results of researches about effectivity of various fungicide treatment schemes in different countries were contradictory. The researches showed that two fungicide applications are not necessary (Bankina et al., 2014), but Wyczling, Lenc \& Sadowski (2010) obtained a better effect after two applications. The results from a research in Nebraska showed that the effect of fungicide application timing at the GS 31 (first node on the stem detectable) versus GS 39 (ligule/collar of flag leaf just visible) on the intensity of leaf blotches or on yield was not consistent. The best predictor of yield losses caused by leaf blotches is disease severity at flowering, and fungicides used at this time can prevent significant yield losses (Wegulo, Breathnach, \& Baenziger, 2009).

Wheat yield

Both trial years were unfavourable for winter wheat yield formation; the average winter wheat yield per two trial years was 5.90-6.20 $\mathrm{t} \mathrm{ha}^{-1}$ depending on variants. A year as a factor significantly influenced wheat yield $(\mathrm{p}<0.001)$. Lower yields $\left(5.03-5.57 \mathrm{t} \mathrm{ha}^{-1}\right)$ were obtained in 2018/2019, when the meteorological conditions from sowing until harvesting were worse for high yield formation even if compared with 2017/2018 which also was not appropriate for high yield development. Other researchers also found that limited water availability significantly reduces grain yield (Racz et al., 2015; Smutná, Elzner, \& Středa, 2018; Hlaváčová et al., 2018).

The results show that nitrogen fertilization significantly increased the average grain yield per both years $(p<0.001)$. The influence of nitrogen rate differed during trial years $(\mathrm{p}<0.05)$. In 2018, a significant yield increase was observed at the nitrogen fertilizer rate $\mathrm{N} 210$ but in 2019 - even at N180. It coincides with other studies which demonstrated that nitrogen application significantly increases the grain yield (Litke, Gaile, \& Ruža, 2017). Assessing the average two-year yield (Figure 4) depending on nitrogen rate, a significant increase of yield was obtained at the rate N180. Further increase of nitrogen rate did not cause a significant increase if compared with N180.

In 2018, when the average wheat yield was higher (6.33-7.33 $\left.\mathrm{t} \mathrm{ha}^{-1}\right)$, a significant distinction was found between variants in which different fungicide treatment schemes were applied, and higher yield on average was gained in the variants without fungicide treatment and in the variant with reduced fungicide dose at GS 55-59. It could be explained by stress for the plants due to the usage of fungicides, drought and hot weather. Fungicides may have negative effects on crop physiology, especially on photosynthesis, resulting in a decrease in both growth and yield of crop plants (Petit et al., 2012). The researchers from Canada reported that using fungicides under dry conditions decreased the yield. Wheat were more resistant to drought than other tested crops, the application of fungicides one time in a growing period (flag leaf was fully emerged) only stressed plants. As a result, the grain yield was similar to non-treated variant although in years with normal amount of precipitation the use of fungicide increased grain yield by $5.2-15.0 \%$ (Kutcher et al., 2011).

In 2019, the fungicide treatment did not significantly affect the wheat yield. Assessing the average two-year yield (Figure 5) depending on fungicide treatment schemes, significant differences were not found. Bhatta et al. (2018) found that efficacy of the foliar fungicide to improve grain yield largely depends on the meteorological conditions and the level of disease severity. In investigations the severity of leaf blotches was low. The results of a research in Poland (Wyczling, Lenc, \& Sadowski, 2010) show that rainfall in the later part of the winter wheat growing season influenced the yield response to fungicide application, but the amount of precipitations in both years of our trial was very low. It is also known, that susceptible cultivars had a larger response 


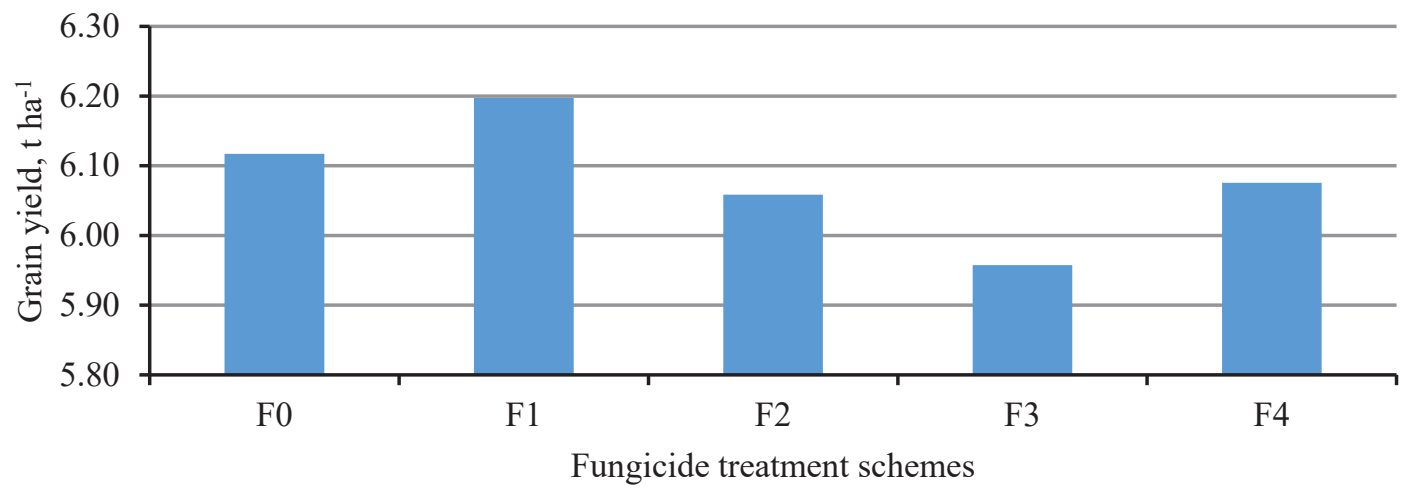

Figure 5. Winter wheat grain yield depending on fungicide treatment schemes

(average data, 2017/2018-2018/2019).

to fungicides than resistant cultivars (Byamukama et al., 2018; Bhatta et al., 2018). Cultivar 'Skagen' used in our trials is characterised as comparatively resistant against diseases.

Leaf blotch disease's severity on upper three leaves at GS 55 and upper two leaves at GS 75 significantly negatively correlated with the yield level. Wegulo, Breathnach, \& Baenziger (2009) found that severity of leaf blotches at GS 60 had the strongest relationship to yield. Jevtić et al. (2017) found that the strongest relationship between values of AUDPC of Septoria leaf blotch and yield includes the period from the end of flowering (GS 69) to milk stage (GS 70-73). In our investigations, the severity of leaf blotches was low at this time and only a weak correlation $(r=0.39, \mathrm{p}$ $<0.001)$ in 2018 between the total sum of AUDPC of tan spot and the yield was observed, but in 2019 - was not observed. A correlation between the total sum of AUDPC of Septoria leaf blotch and the yield was not observed.

\section{Conclusions}

The severity of leaf blotches in winter wheat was low in both years due to the dry and hot weather and did not influence the winter wheat grain yield significantly. Nitrogen fertilization increased the winter wheat grain yield, but did not have a significant effect on the development of leaf blotches. A significant average yield increase was obtained till the nitrogen rate of N180, further increase of nitrogen rate did not cause a significant increase of yield.

Fungicide treatment schemes had no significant effect on the average grain yield but decreased the development of leaf blotches significantly. The using of full dose of fungicide at the GS 55-59 as well as using fungicides two or three times in the growing season significantly decreased the values of AUDPC for both diseases, but differences among AUDPC values in the three mentioned variants were not significant.

There was an untypically low amount of precipitation in both trial years and further studies are necessary to investigate different meteorological conditions and various levels of leaf blotch development.

\section{Acknowledgements}

The research was supported by the EIP-AGRI project 'The development of the decision-making support system for restriction of the diseases, affecting leaves and ears of winter wheat'.

\section{References}

Bankina, B., Gaile, Z., Balodis, O., Bimšteine, G., Katamadze, M., Kreita, Dz., Paura, L., \& Priekule, I. (2014). Harmful winter wheat diseases and possibilities for their integrated control in Latvia. Acta Agriculturae Scandinavica, Section B - Soil \& Plant Science, 64(7), 615-622. DOI: 10.1080/09064710.2014.949296.

Bankina, B., Bimšteine, G., Arhipova, I., Kaņeps, J., \& Stanka, T. (2018a). Importance of agronomic practice on the control of winter wheat diseases. Agriculture, 8, 56. DOI: 10.3390/agriculture8070056.

Bankina, B., Stanka, T., \& Grickeviča, K. (2018b). Kviešu lapu attīstība atkarībā no fungicīdu smidzināšanas shēmas (Development of wheat leaf diseases depending on fungicide application schemes). No Ražas svētki 'Vecauce - 2018': Latvijai - 100, Lauksaimniecības izglītībai - 155. Zinātniskā semināra (2018. g. 1. novembris) rakstu krājums (13.-16. lpp.). Vecauce, Latvija. (in Latvian with English abstract).

Bhatta, M., Regassa, T., Wegulo, S., \& Baenziger, P.S. (2018). Foliar fungicide effects on disease severity, yield and agronomic characteristics of modern winter wheat genotypes. Agronomy Journal, 110 (2), 1-9. DOI: 10.2134/agronj2017.07.0383. 
Byamukama, E., Ali, S., Kleinjan, J., Yabwalo, D.N., Graham, C., Caffe-Treml, M., Mueller, N.D., Rickertsen, J., \& Berzonsky, W.A. (2019). Winter wheat grain yield response to fungicide application is influenced by cultivar and rainfall. The Plant Pathology Journal, 35(1), 63-70. DOI: 10.5423/ORJ.OA.2018.0056.

Castro, M.K., Fleitas, M.C., Scierenbeck, M., Gerard, G.S., \& Simón, M.R. (2018). Evaluation of different fungicides and nitrogen rates on grain yield and bread-making quality in wheat affected by Septoria triticibloch and yellow spot. Journal of Cereal Science, 83, 49-57. DOI: 10.1016/j.jcs.2018.07.014.

Fleitas, M.C., Scierenbeck, M., Gerard, G.S., Dietz, J.I., Golik, S.I., \& Simón, M.R. (2018). Breadmaking quality and yield response to the green leaf area duration caused by fluxapyroxad under three nitrogen rates in wheat affected with tan spot. Crop Protection, 106, 201-2019. DOI: 10.1016/j.cropro.2018.01.004.

Hlaváčová, M., Klem, K., Rapantová, B., Novotná, K., Urban, O., Hlavinka, P., ... Trnka, M. (2018). Interactive effects of high temperature and drought stress during stem elongation, anthesis and early grain filling on the yield formation and photosynthesis of winter wheat. Field Crop Research, 221, 182-195. DOI: 10.1016/j.fcr.2018.02.022.

Jevtić, R., Župunski, V., Lalošević, M., \& Župunski, L. (2017). Predicting potential winter wheat losses caused by multiple disease systems and climatic conditions. Crop Protection, 99, 17-25. DOI: 10.1016/j. cropro.2017.05.005.

Kutcher, H.R., Johnston, A.M., Bailey, K.L., \& Malhi, S.S. (2011). Managing crop losses from plant diseases with foliar fungicides, rotation and tillage on a Black Chernozem in Saskatchewan, Canada. Field Crops Research, 124, 205-212. DOI: 10.1016/j.fcr.2011.05.018.

Liniña, A., \& Ruža, A. (2018). The influence of cultivar, weather conditions and nitrogen fertilizer on winter wheat grain yield. Agronomy Research, 16(1), 147-156. DOI: 10.15159/AR.18.034.

Litke, L., Gaile, Z., \& Ruža, A. (2017). Nitrogen fertilizer influence on winter wheat yield and yield components depending on soil tillage and forecrop. In 'Research for Rural Development 2017' $23^{\text {rd }}$ Annual International Scientific Conference Proceedings, 17-19 May 2017 (pp. 54-61). Jelgava: LLU. DOI: 10.22616/ rrd.23.2017.049.

Petit, A.N., Fontaine, F., Vatsa, P., Clément, C., Vaillant-Gaveau, N. (2012). Fungicide impacts on photosynthesis in crop plants. Photosynthesis Research, 111, 315-326. DOI: 10.1007/s11120-012-9719-8

Racz, I., Kadar, R., Moldovan, V., \& Haş, I. (2015). Performance and stability of grain yield and yield components in some winter wheat varieties. Romanian Agricultural Research, 32, 11-18.

Ronis, A., \& Semaškiene, R. (2011). Relationship of AUDPC values of tan spot and Stagonospora glume blotch with grain infection in winter and spring wheat. Zemdirbyste = Agriculture, 98(1), 11-18.

Serrago, R.A., Carretero, R., Bancal, M.O., \& Miralles, D.J. (2011). Grain weight response to foliar diseases control in wheat (Triticum aestivumL.). Field Crops Research, 120, 352-359. DOI: 10.1016/j. fcr.2010.11.004

Smutná, P., Elzner P., \& Středa T. (2018). The effect of water deficit on yield and yield component variation in winter wheat. Agriculturae Conspectus Scientificus, 82(1), 105-111.

Stanka, T., Bankina, B., \& Daugaviņa, L. (2019). Kviešu lapu plankumainību ierobežošanas efektivitāte atkarībā no fungicīdu smidzināšanas shēmas (Control efficiency of wheat leaf blotches depending on fungicide application schemes). In Ražas svētki 'Vecauce - 2019':Gaidot starptautisko zinātnes izvērtējumu. Zinātniskā semināra (2019. g. 7. novembris) rakstu krājums (45.-48. lpp.). Vecauce, Latvija. (in Latvian with English abstract).

Wegulo, S.N., Breathnach, J.A., \& Baenziger, P.S. (2009). Effect of growth stage on the relationship between tan spot and spot blotch severity and yield in winter wheat. Crop Protection, 28, 696-702. DOI: 10.1016/j. cropro.2009.04.003.

Wiik, L. (2009). Yield and disease control in winter wheat in southern Sweden during 1977-2005. Crop Protection, 28, 82-89. DOI: 10.1016/j.cropro.2008.09.002.

Wyczling, D., Lenc, L., \& Sadowski, C. (2010). Comparison of disease occurrence and green leaf area (GLA) of winter wheat depending on the forecrop and differentiated fungicidal protection used. Journal of Plant Protection Research, 50(4), 489-495. DOI: 10.2478/v10045-010-0081-6. 